Modified Level II Streambed-Scour

Analysis for Structure 1-74-70-4437

Crossing Eagle Creek

in Marion County, Indiana

By BRET A. ROBINSON, DAVID C. VOELKER, and ROBERT L. MILLER

Prepared in cooperation with the INDIANA DEPARTMENT OF TRANSPORTATION

U.S. GEOLOGICAL SURVEY

Open-File Report 97-308

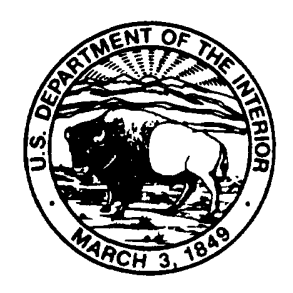

Indianapolis, Indiana 


\section{U.S. DEPARTMENT OF THE INTERIOR \\ BRUCE BABBITT, Secretary \\ U.S. GEOLOGICAL SURVEY \\ Gordon P. Eaton, Director}

For additional information, write to:

District Chief

U.S. Geological Survey

Water Resources Division

5957 Lakeside Boulevard

Indianapolis, IN 46278-1996
Copies of this report can be purchased from:

U.S. Geological Survey

Branch of Information Services

Box 25286

Federal Center

Denver, CO 80225 


\section{CONTENTS}

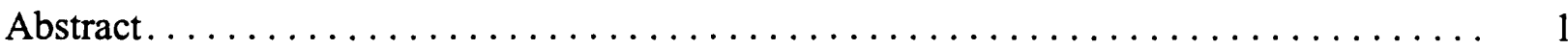

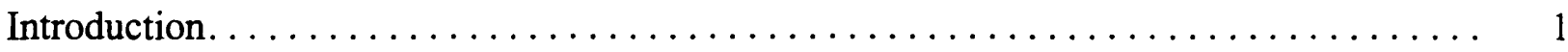

Background and Scope $\ldots \ldots \ldots \ldots \ldots \ldots \ldots \ldots \ldots \ldots \ldots \ldots \ldots \ldots \ldots \ldots \ldots \ldots \ldots$

Site Description................................. 2

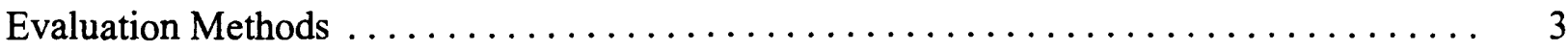

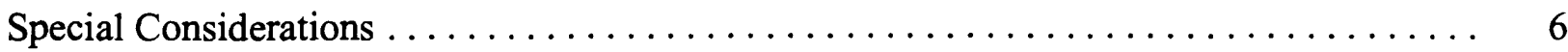

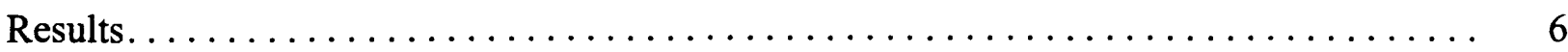

References.......................................... 6

Appendix............................................ 7

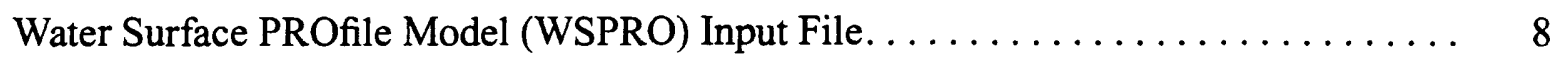

Water Surface PROfile Model (WSPRO) Output .................... 9

Tables

1. Cumulative scour depths for the modeled discharges at structure I-74-70-4437 crossing Eagle Creek in Marion County, Indiana. 


\section{CONVERSION FACTORS AND ABBREVIATIONS}

\begin{tabular}{rll}
\hline Multiply & By & To obtain \\
\hline inch (in.) & 25.4 & millimeter \\
foot (ft) & 0.3048 & meter \\
square foot $\left(\mathrm{ft}^{2}\right)$ & 929.0 & square centimeter \\
feet per second $(\mathrm{ft} / \mathrm{s})$ & 0.3048 & meters per second \\
cubic foot per second $\left(\mathrm{ft}^{3} / \mathrm{s}\right)$ & 0.02832 & cubic meter per second \\
mile $\left(\mathrm{mi}^{2}\right)$ & 1.609 & kilometer \\
square mile $\left(\mathrm{mi}^{2}\right)$ & 2.590 & square kilometer \\
\hline
\end{tabular}

ABBREVIATIONS used in this report:

$\begin{aligned} \mathrm{D}_{50} & \text { median diameter of bed material } \\ \text { Q100 } & \text { 100-year discharge } \\ \text { FEMA } & \text { Federal Emergency Management Agency } \\ \text { HEC } & \text { Hydraulic Engineering Circular } \\ \text { IDNR } & \text { Indiana Department of Natural Resources } \\ \text { INDOT } & \text { Indiana Department of Transportation } \\ \text { USGS } & \text { United States Geological Survey } \\ \text { WSPRO } & \text { Water Surface PROfile model }\end{aligned}$




\title{
Modified Level II Streambed-Scour Analysis for Structure 1-74-70-4437 Crossing Eagle Creek in Marion County, Indiana
}

By Bret A. Robinson, David C. Voelker, and Robert L. Miller

\begin{abstract}
Level II scour evaluations follow a process in which hydrologic, hydraulic, and sedimenttransport data are evaluated to calculate the depth of scour that may result when a given discharge is routed through a bridge opening. The results of the modified Level II analysis for structure I-74-70-4437 on Interstate 74 crossing Eagle Creek in Marion County, Indiana, are presented. The site is near the town of Clermont in the northwestern part of Marion County. Scour depths were computed with the Water Surface PROfile model, version V050196, which incorporates the scour-calculation procedures outlined in Hydraulic Engineering Circular No. 18. Total scour depths at the piers were approximately 16.0 feet for the modeled discharge of 22,700 cubic feet per second and approximately 31.7 feet for the modeled discharge of 31,600 cubic feet per second.
\end{abstract}

\section{INTRODUCTION}

The U.S. Geological Survey (USGS), in cooperation with the Indiana Department of Transportation (INDOT), is conducting Level II scour analyses at a number of bridges throughout Indiana. This report describes the methods applied and the modeling results for bridge I-74-70-4437.

\section{Background and Scope}

Level I scour assessment is a process where a large number of bridges are studied as a group. Assessments usually are made by evaluating a combination of geomorphic, hydrologic, and bridge-characteristic data. The results help investigators determine which bridges appear to be most likely to experience streambed-scour problems and which bridges appear to be relatively immune to problems brought on by streambed scour (for example, bridges built on bedrock). 
When applied correctly, Level I scour assessments provide an investigator with information to identify those bridges that appear to be relatively safe and those bridges that fall into higher risk categories.

Level II scour evaluations describe the process for an investigator to apply a model to a bridge site and calculate the potential depth of scour that may result from a given flood event. Level II analyses involve the application of basic hydrologic, hydraulic, and sediment-transport engineering concepts and may include an evaluation of flood history, channel hydraulic conditions (for example, water-surface profile analysis), and basic sediment-transport analyses such as scour calculations (Lagasse and others, 1995).

The methods and model outlined in Hydraulic Engineering Circular (HEC) No. 18 (Richardson and Davis, 1995) formulate the basis for Level II scour evaluations. Methods used in this study for Level II scour evaluations are a modification of the HEC-18 standards. These modifications were made to comply with the methodology requested by INDOT (Merril Dougherty, Indiana Department of Transportation, oral commun., 1996). Descriptions of the specific modifications are given in the "Evaluation Methods" section of this report.

This report presents the methods followed for modeling, special considerations for this study site, and the input for and the output from the Water Surface PROfile (WSPRO) model.

\section{Site Description}

The study site is located near the town of Clermont in the northwestern part of Marion County. This site is immediately downstream from the Eagle Creek Reservoir Dam. The drainage area for the site is approximately $168 \mathrm{mi}^{2}$ (estimated using Hoggatt, 1975, and USGS 7.5-minute topographic data). The predominant land uses in the basin are suburban and agricultural; in the immediate vicinity of the bridge, the land is predominantly grassy with forest nearby.

Within the immediate vicinity of the bridge, Eagle Creek has a channel-bed slope of approximately $0.0012 \mathrm{ft} / \mathrm{ft}$. The channel-bed material is cobbley sandy silt-clay, and the channel banks consist of gravelly sandy silt/clay. At the time of the Level I site visit on June 26, 1995, the banks were observed to have 0 to 50 percent woody vegetative cover; the field report noted that the banks were experiencing some fluvial erosion.

The Interstate 74 crossing of Eagle Creek is a 252 -ft-long, multi-lane bridge consisting of five spans supported by concrete and steel piers and sloping earthen spill-through abutments. Additional details describing conditions at the site are included in the Level I data base (Hopkins and Robinson, unpub. data, 1997). Photographs of the site, taken at the time of the Level I site visit, are archived at the USGS office in Indianapolis. 


\section{EVALUATION METHODS}

The methods described in this section apply to a number of bridge sites in Indiana being evaluated for scour and outline the procedures requested by INDOT for these modified Level II scour analyses. The principal modification requested by INDOT was that the input data to the model come from or be estimated from existing data sources; no additional field data were collected. Actual methods used in the scour evaluation at this particular bridge site use the most applicable method possible, given the data available.

To determine drainage area, either published values found in Hoggatt (1975) or 7.5-minute topographic maps with Hoggatt's original drainage-area delineations were used. Where there are no published data, drainage-area segments measured from the maps produced by Hoggatt were either subtracted from downstream sites or added to upstream sites published by Hoggatt (1975).

In Indiana, flood discharges are coordinated by agreement among State and Federal agencies. At sites where flood discharges officially are coordinated among State and Federal agencies in Indiana, the coordinated 100-year discharge (Q100) was modeled. INDOT also provided an additional flood discharge for these coordinated sites in excess of the Q100 to be modeled.

If a flood discharge was not coordinated, the USGS examined Federal Emergency Management Agency (FEMA) studies for Q100 determinations. Where FEMA studies did not produce a Q100, the USGS contacted IDNR for an estimated Q100 in the vicinity of the site being studied. If IDNR did not have a Q100, data from nearby USGS streamflow-gaging stations were analyzed with nearby and similar drainage basins that have been coordinated. At sites having no coordinated discharge data, the two discharges used in the model were 1) the approximated Q100 and 2) a discharge equal to 1.7 times the approximated Q100.

Most of the cross-section and bridge-opening geometry data were taken from the bridge plans (Indiana State Highway Commission, 1958) provided by INDOT. Bridge plans are presumed to be representative of current conditions at the site. To determine the cross-section geometry, a line was drawn on the bridge plans parallel to the bridge stationing and approximately one bridge width from the bridge. For sites where the bridge plans did not extend far enough laterally for collection of all cross-section data required for WSPRO model analysis, additional data were collected from 7.5-minute topographic maps.

The roadway and embankment profile was taken from the bridge and highway plans for those sites where roadway overtopping was expected. The INDOT bridge plans and 7.5-minute topographic maps were used as a guide, based on the water-surface elevations calculated by the WSPRO model, to determine if roadway overtopping might occur. 
Roughness values ( $n$-values) for the main channel were estimated by viewing photographs archived from the Level I scour assessments. The $n$-values for the overbanks were assigned on the basis of the surface-cover data summarized in the Level I data base (Hopkins and Robinson, unpub. data, 1997). From those data, the following roughness values were assigned to the surface-cover categories: urban -0.050 , suburban -0.035 , row crop -0.045 , pasture -0.035 , brush -0.120 , forest -0.100 , and wetland (any area covered by standing water) -0.100 . The $n$-values for the overbanks were adjusted if the Level I photographs provided sufficient detail to warrant an adjustment.

WSPRO version V050196 was used to model flow through the study site. Starting watersurface elevation was obtained with a slope-conveyance computation. The channel-bed slope in the immediate vicinity of the bridge was estimated from the 7.5-minute topographic map and was used as the slope of the energy grade line for this computation.

WSPRO version V050196 includes a field that allows the input of up to four scour-adjustment factors ( $\mathrm{K} 1$ to $\mathrm{K} 4$ ). For this modeling, the default value for $\mathrm{K} 4$ (bed armoring) was chosen. For scour-adjustment factors $\mathrm{K} 1$ and $\mathrm{K} 2$ (pier-nose shape and angle of attack, respectively), input values were determined by evaluating the data archived in the Level I data base (Hopkins and Robinson, unpub. data, 1997). For the $\mathrm{K} 3$ factor (bed forms), a value of 1.1 was applied in all cases.

In some cases, piers set on the overbanks are constructed with footings that are higher in elevation than pier footings in the main channel. In these situations, if the channel position changes, the piers that were initially constructed on the overbank may become part of the main channel. Therefore, to evaluate total potential scour, the model results obtained for contraction scour and deepest local scour in the main channel were added and applied to all piers in the bridge opening. This methodology allowed for an evaluation of potential undermining of pier supports in the event that future channel movement placed overbank piers in the main channel.

Where bridge pairs have a continuous abutment or fill between the bridges that does not allow expansion of flow, the bridge pair was modeled as one bridge. Sites with discontinuous abutments, allowing expansion between the bridges, were modeled as two separate bridges. In those cases, a valley cross section was measured between the bridges and used as the approach section for the downstream bridge and as the exit section for the upstream bridge.

At sites with no embankment to function as a weir or at sites where the tailwater drowns out the embankment, a composite bridge and road section was used to compute flow. Those sites were computed with friction-loss equations rather than with a bridge routine.

Total scour is taken as the sum of local scour plus contraction scour. If the model predicted negative contraction scour (aggradation), the contraction-scour value was assumed to be zero in determining the total scour depth (table 1). This assumption was made so that a negative contraction scour would not mask the potentially detrimental effects of local scour at a pier. No abutment scour evaluations were made in this study. 
Table 1. Cumulative scour depths for the modeled discharges at structure 1-74-70-4437 crossing Eagle Creek in Marion County, Indiana

$[--$, no value $]$

\begin{tabular}{|c|c|c|c|c|c|c|c|}
\hline $\begin{array}{c}\text { Pier } \\
\text { number }{ }^{1}\end{array}$ & $\begin{array}{c}\text { Stationing } \\
\text { from } \\
\text { bridge } \\
\text { plans }\end{array}$ & $\begin{array}{l}\text { Initial } \\
\text { bed- } \\
\text { elevation } \\
\text { at pier } \\
\text { (feet) }\end{array}$ & $\begin{array}{l}\text { Main- } \\
\text { channel } \\
\text { contrac- } \\
\text { tion scour } \\
\text { depth } \\
\text { (feet) }\end{array}$ & $\begin{array}{l}\text { Local } \\
\text { scour } \\
\text { depth } \\
\text { (feet) }\end{array}$ & $\begin{array}{l}\text { Worst- } \\
\text { case } \\
\text { total- } \\
\text { scour } \\
\text { depth } \\
\text { (feet) }\end{array}$ & $\begin{array}{c}\text { Bottom } \\
\text { elevation } \\
\text { of pier } \\
\text { (feet) }\end{array}$ & $\begin{array}{l}\text { Worst- } \\
\text { case bed } \\
\text { elevation } \\
\text { after } \\
\text { scour } \\
\text { (feet) }\end{array}$ \\
\hline \multicolumn{8}{|c|}{ Modeled discharge ${ }^{5}$ is 22,700 cubic feet per second } \\
\hline 1 & $749+06$ & 753 & 9.0 & 7.0 & 16.0 & 737.4 & 724.5 \\
\hline 2 & $749+67$ & 741 & 9.0 & 7.0 & 16.0 & 734.4 & 724.5 \\
\hline 3 & $750+39$ & 741 & 9.0 & 7.0 & 16.0 & 734.4 & 724.5 \\
\hline 4 & $751+00$ & 753 & 9.0 & 7.0 & 16.0 & 737.4 & 724.5 \\
\hline \multicolumn{8}{|c|}{ Modeled discharge is 31,600 cubic feet per second } \\
\hline 1 & $749+06$ & 753 & 23.9 & 7.8 & 31.7 & 737.4 & 708.8 \\
\hline 2 & $749+67$ & 741 & 23.9 & 7.8 & 31.7 & 734.4 & 708.8 \\
\hline 3 & $750+39$ & 741 & 23.9 & 7.8 & 31.7 & 734.4 & 708.8 \\
\hline 4 & $751+00$ & 753 & 23.9 & 7.8 & 31.7 & 737.7 & 708.8 \\
\hline
\end{tabular}

${ }^{1}$ Pier numbers were assigned from left to right as shown on the bridge plans.

${ }^{2}$ Stationing is the center line of the pier as determined from the bridge plans. Stationing from bridge plan, $749+06$, represents a point 74,906 feet from an arbitrary starting location referenced on the bridge plans.

${ }^{3}$ Worst-case total-scour depths are generated by summing the calculated contraction-scour depth with the worst case of local scour.

${ }^{4}$ Worst-case bed elevation is computed by subtracting the worst-case total-scour depth from the lowest initial bed elevation in the bridge opening ( 740.5 feet).

${ }^{5}$ Coordinated discharge. 


\section{SPECIAL CONSIDERATIONS}

Model runs indicate the water-surface elevation at the bridge is lower than the low-steel elevation for the modeled discharges. Therefore, there should be no pressure flow through the bridge opening for the discharges modeled. This site has been modeled without consideration for how Eagle Creek Reservoir affects the hydraulics or streambed-scour conditions.

\section{RESULTS}

Scour depths were computed with a version of WSPRO (Larry Arneson, Federal Highway Administration, written commun., 1996) modified from Shearman (1990). This version of WSPRO includes scour calculations in the model output. Scour depths were calculated assuming an infinite depth of material that could erode and a homogeneous particle-size distribution. The results of the scour analysis are presented in table 1; a complete input file and output results are presented in the appendix.

\section{REFERENCES}

Hoggatt, R.E., 1975, Drainage areas of Indiana streams: U.S. Geological Survey, Water Resources Division, $231 \mathrm{p}$.

Indiana State Highway Commission, 1958, Bridge plans Interstate Route 74: Bridge File I-74-70-4437.

Lagasse, P.F.; Schall, J.D.; Johnson, F.; Richardson, E.V.; and Chang, F., 1995, Stream stability at highway structures ( $2 \mathrm{~d}$ ed.): Federal Highway Administration, Hydraulic Engineering Circular No. 20, Publication FHWA-IP-90-014, 144 p.

Richardson, E.V., and Davis, S.R., 1995, Evaluating scour at bridges (3d ed.): Federal Highway Administration, Hydraulic Engineering Circular No. 18, Publication FHWA-IP-90-017, $204 \mathrm{p}$.

Shearman, J.O., 1990, User's manual for WSPRO, a computer model for water-surface profile computations: Federal Highway Administration Publication FHWA-IP-89-027, $177 \mathrm{p}$. 
APPENDIX 


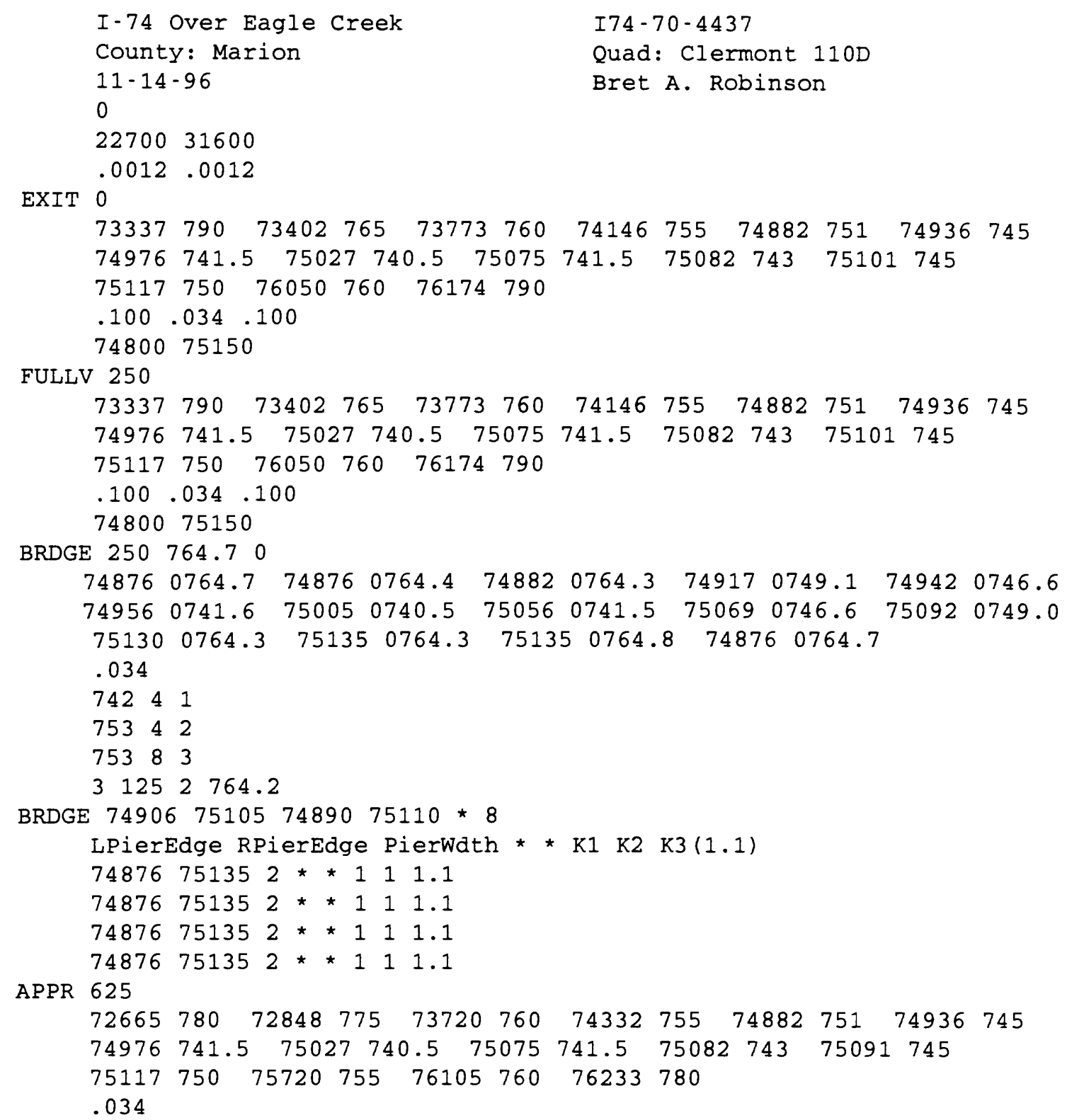

I74- $70-4437$

Quad: Clermont 110D

Bret A. Robinson

*
DP
DP
DP
DP
XS
GR
GR
GR
$N$ X 


\section{WSPRO OUTPUT}

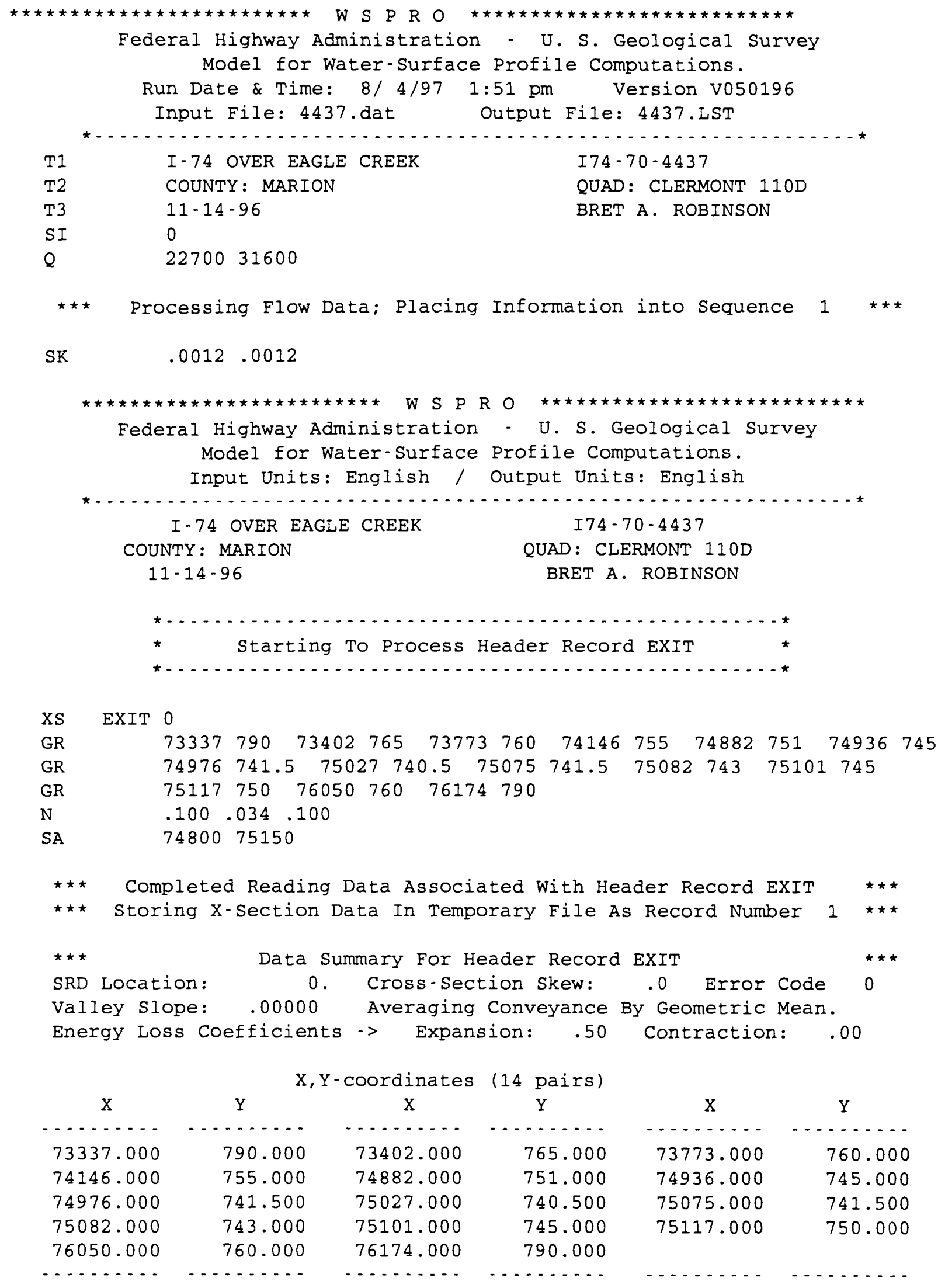




\section{WSPRO OUTPUT}

Minimum and Maximum $X, Y$-coordinates

$\begin{array}{lrl}\text { Minimum X-Station: } & 73337.000 & \text { ( associated Y-Elevation: } 790.000) \\ \text { Maximum X-Station: } & 76174.000 & \text { ( associated Y-Elevation: } 790.000) \\ \text { Minimum Y-Elevation: } & 740.500 & \text { ( associated X-Station: } 75027.000) \\ \text { Maximum Y-Elevation: } & 790.000 & \text { (associated X-Station: } 73337.000)\end{array}$

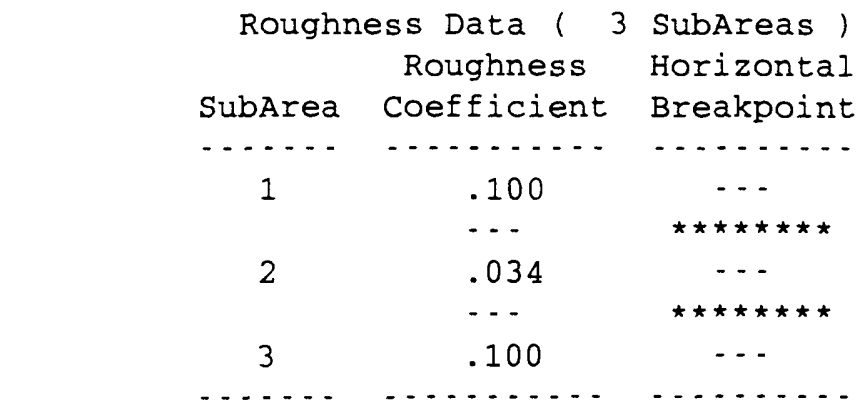

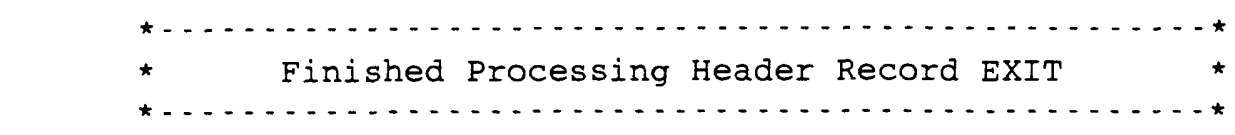

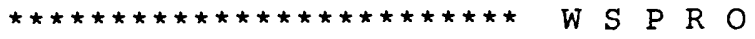

Federal Highway Administration Model for Water-Surface Input Units: English / Output Units: English

\section{I-74 OVER EAGLE CREEK}

COUNTY : MARION

$11-14-96$
U. S. Geological Survey

Profile Computations.

I74- $70-4437$

QUAD: CLERMONT 110D

BRET A. ROBINSON

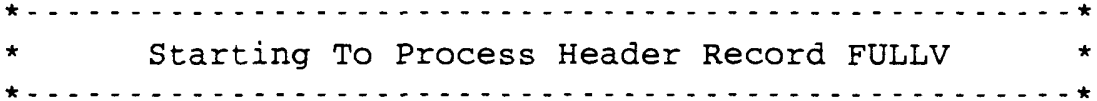

XS

GR

GR

GR

$\mathrm{N}$

$\mathrm{SA}$

FULLV 250

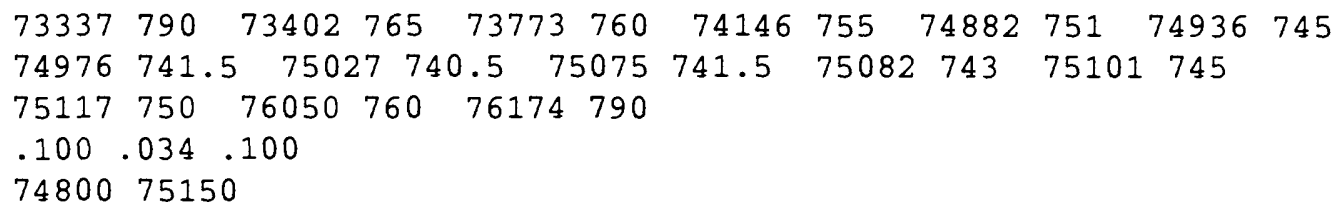

*** Completed Reading Data Associated With Header Record FULLV ***

$\star \star *$ Storing $X$-Section Data In Temporary File As Record Number $2 * \star *$

*** Data Summary For Header Record FULLV

SRD Location: 250. Cross-Section Skew: .0 Error Code 0 Valley Slope: .00000 Averaging Conveyance By Geometric Mean. Energy Loss Coefficients $\rightarrow$ Expansion: .50 Contraction: .00

\begin{tabular}{|c|c|c|c|c|c|}
\hline \multicolumn{6}{|c|}{$\mathrm{X}, \mathrm{Y}$-coordinates (14 pairs) } \\
\hline $\mathrm{x}$ & Y & $\mathrm{x}$ & $\mathrm{Y}$ & $x$ & Y \\
\hline & & & & 7377300 & \\
\hline 73337.000 & 790.000 & 73402.000 & 765.000 & 73773.000 & 760.000 \\
\hline 74146.000 & 755.000 & 74882.000 & 751.000 & 74936.000 & 745.000 \\
\hline
\end{tabular}




\section{WSPRO OUTPUT}

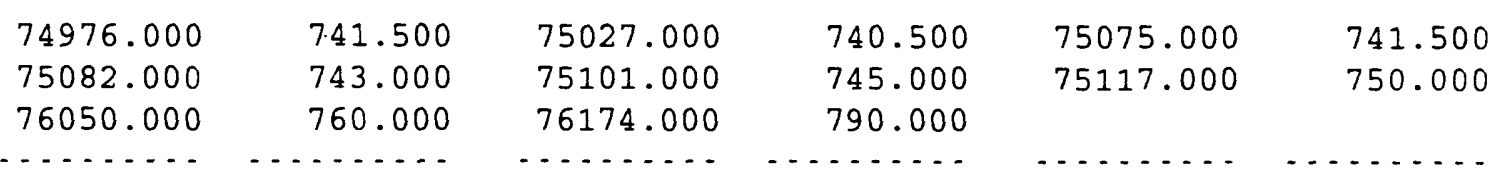

Minimum and Maximum X,Y-coordinates

$\begin{array}{lrlr}\text { Minimum X-Station: } & 73337.000 & \text { ( associated Y-Elevation: } 790.000) \\ \text { Maximum X-Station: } & 76174.000 & \text { ( associated Y-Elevation: } 790.000) \\ \text { Minimum Y-Elevation: } & 740.500 & \text { ( associated X-Station: } 75027.000) \\ \text { Maximum Y-Elevation: } & 790.000 & \text { (associated X-Station: } 73337.000)\end{array}$

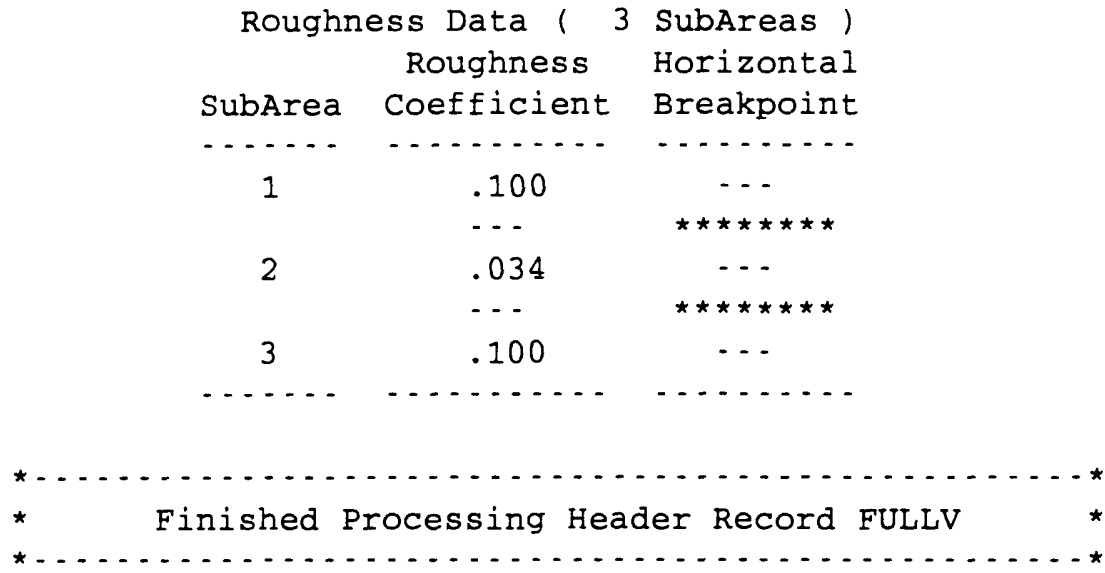

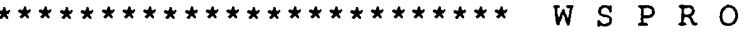

Federal Highway Administration

U. S. Geological Survey

Model for water-Surface Profile Computations.

Input Units: English / Output Units: English

I -74 OVER EAGLE CREEK
COUNTY: MARION
$\begin{aligned} & 11-14-96 \\ & \text { QUAD: CLERMONT } 110 \mathrm{D}\end{aligned}$
BRET A. ROBINSON

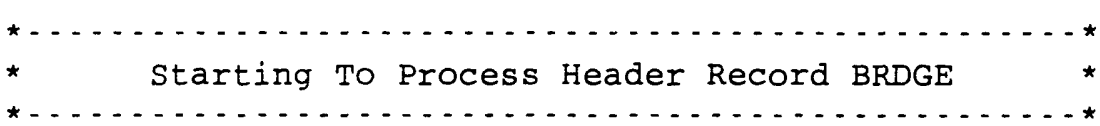

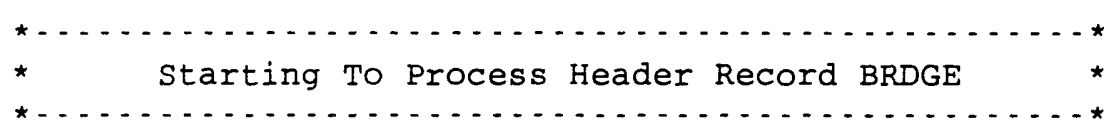

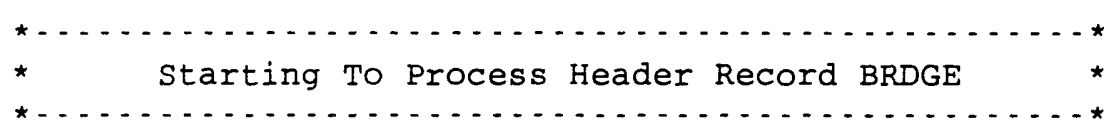

BRET A. ROBINSON
}

BR

$\mathrm{GR}$

0746.6

GR

0749.0

GR

$\mathrm{N}$

PD

PD

$\mathrm{PD}$

$\mathrm{CD}$
BRDGE $250764.7 \quad 0$

$74876 \quad 0764.7$

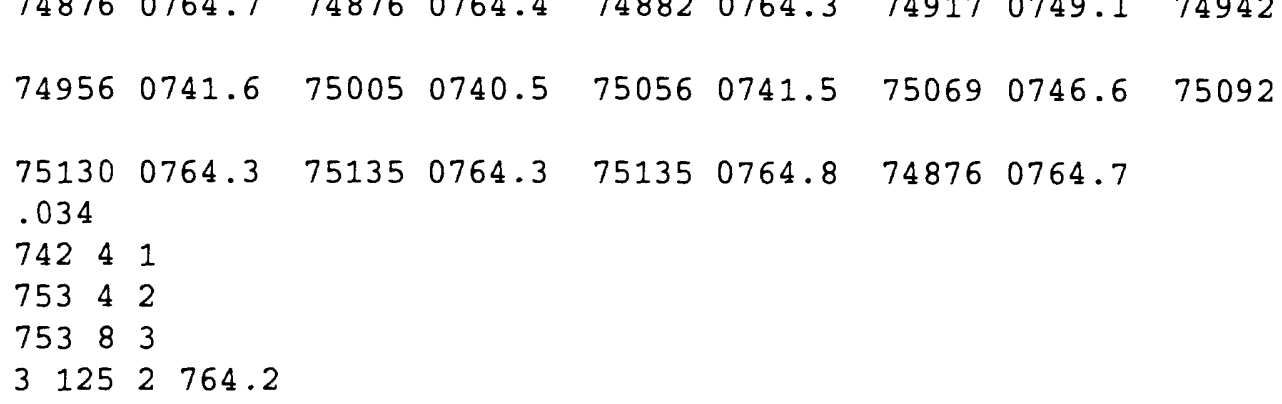

$\star \star \star$ Completed Reading Data Associated With Header Record BRDGE $\star \star \star ~$ +++072 NOTICE: $X$-coordinate \# 2 increased to eliminate vertical segment. +++072 NOTICE: $X$-coordinate \#13 increased to eliminate vertical segment. 


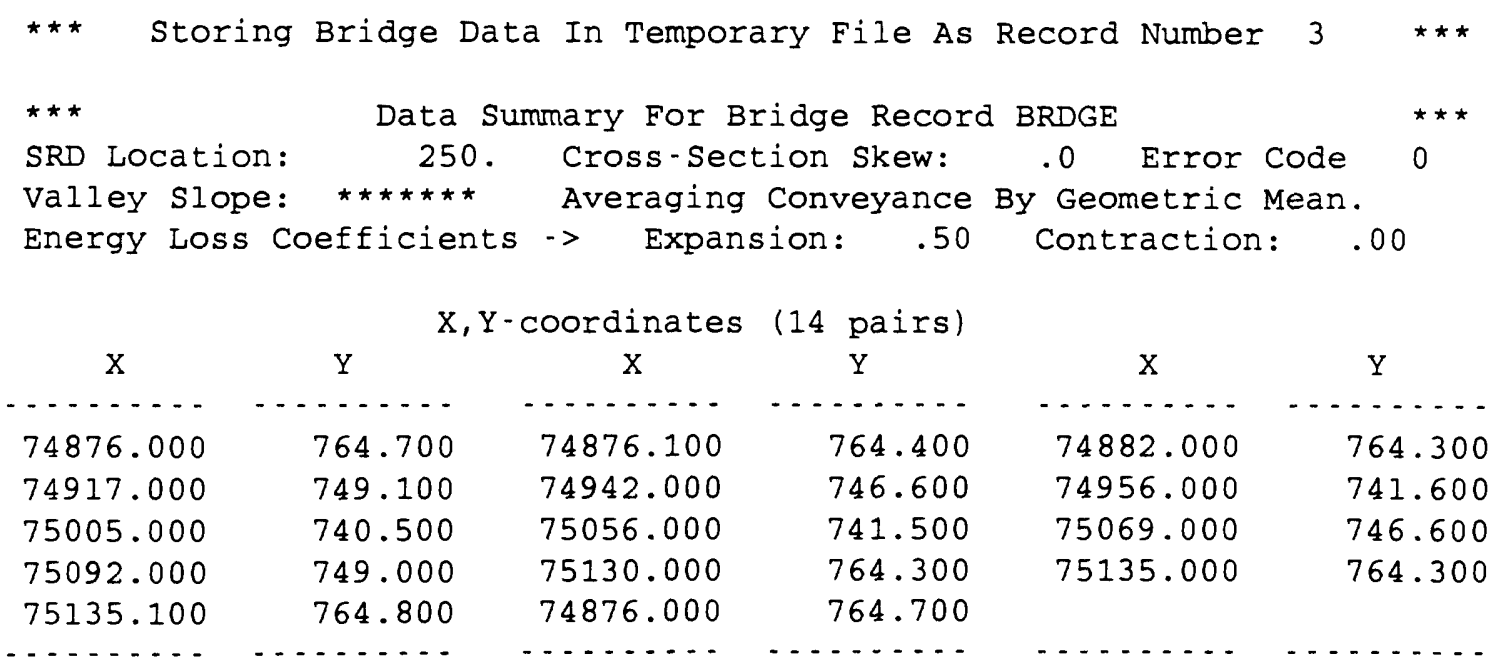

Minimum and Maximum X, Y-coordinates

$\begin{array}{lrlr}\text { Minimum X-Station: } & 74876.000 & \text { ( associated Y-Elevation: } 764.700) \\ \text { Maximum X-Station: } & 75135.100 & \text { ( associated Y-Elevation: } 764.800) \\ \text { Minimum Y-Elevation: } & 740.500 & \text { ( associated X-Station: } 75005.000) \\ \text { Maximum Y-Elevation: } & 764.800 & \text { ( associated X-Station: } 75135.100)\end{array}$

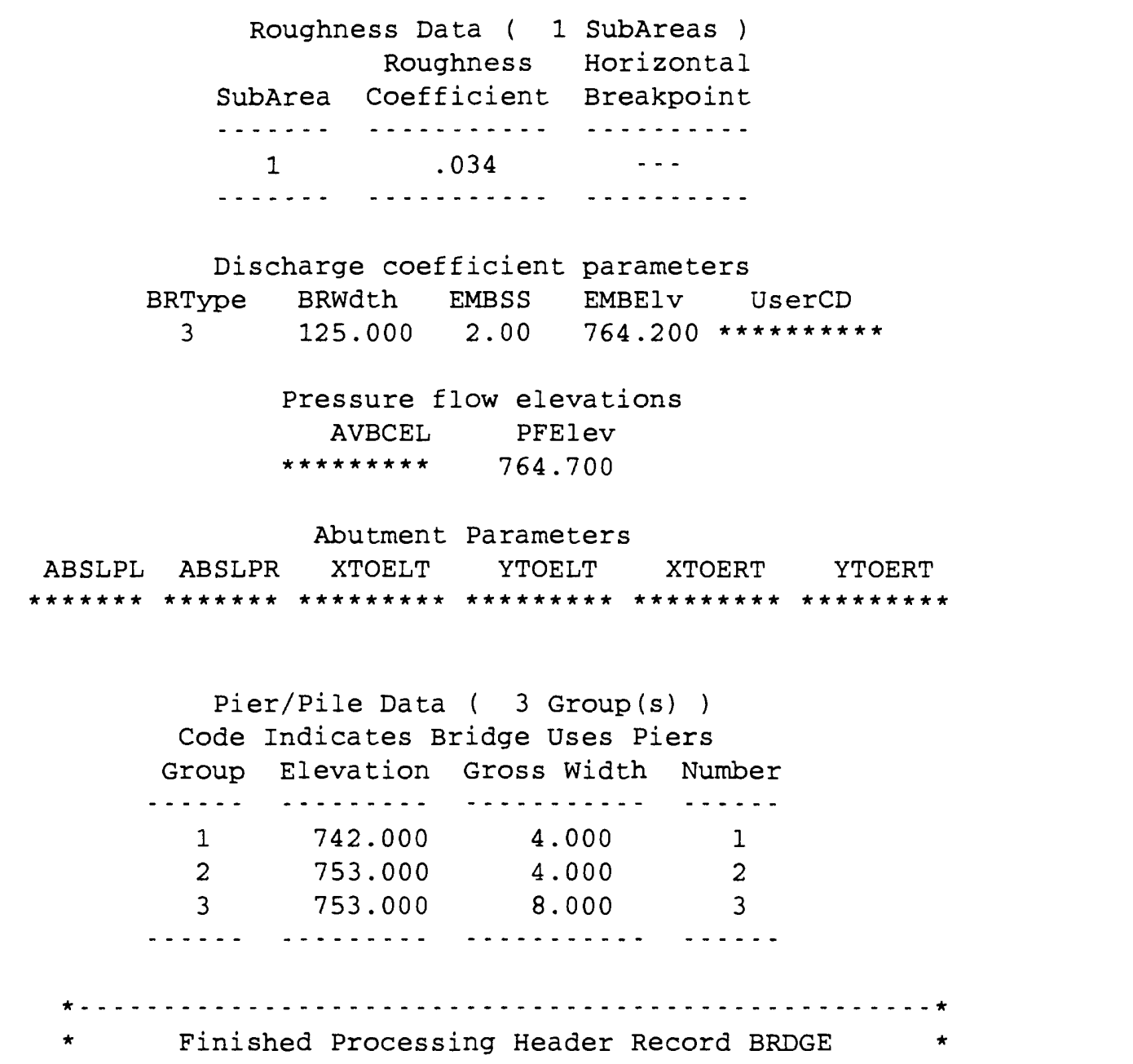




\section{WSPRO OUTPUT}

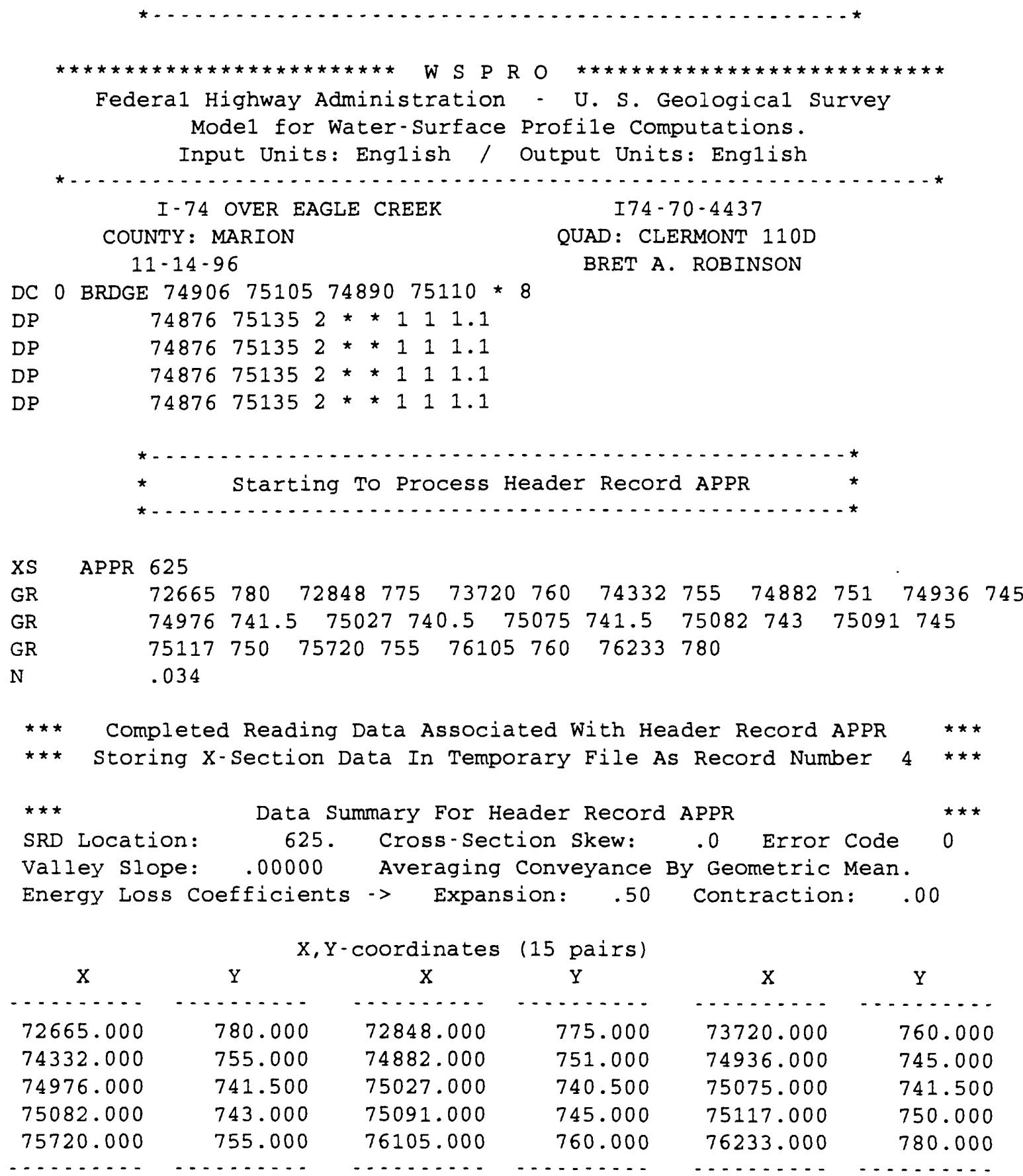

Minimum and Maximum X, Y-coordinates

$\begin{array}{lrlr}\text { Minimum X-Station: } & 72665.000 & \text { ( associated Y-Elevation: } 780.000) \\ \text { Maximum X-Station: } & 76233.000 & \text { ( associated Y-Elevation: } 780.000) \\ \text { Minimum Y-Elevation: } & 740.500 & \text { ( associated X-Station: } 75027.000 \text { ) } \\ \text { Maximum Y-Elevation: } & 780.000 & \text { ( associated X-Station: } 72665.000 \text { ) }\end{array}$

Roughness Data ( 1 SubAreas )
Roughness
Subarea Coefficient Breakpoint




\section{WSPRO OUTPUT}

$\begin{array}{ccc}1 & .034 & \ldots \\ \ldots & \ldots . . . & \ldots\end{array}$

Bridge datum projection(s): XREFLT XREFRT FDSTLT FDSTRT

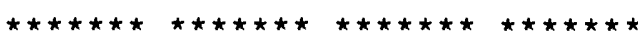

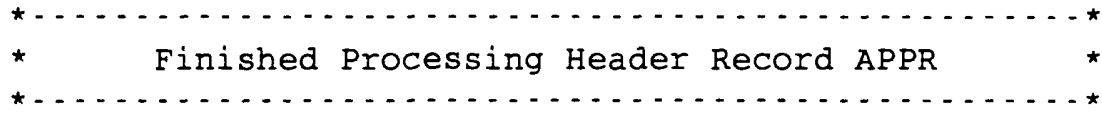

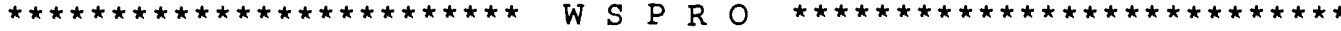
Federal Highway Administration - U. S. Geological Survey Model for Water-Surface Profile Computations.
Input Units: English / Output Units: English
QUAD: CLERMONT 110D
BRET A. ROBINSON

EX

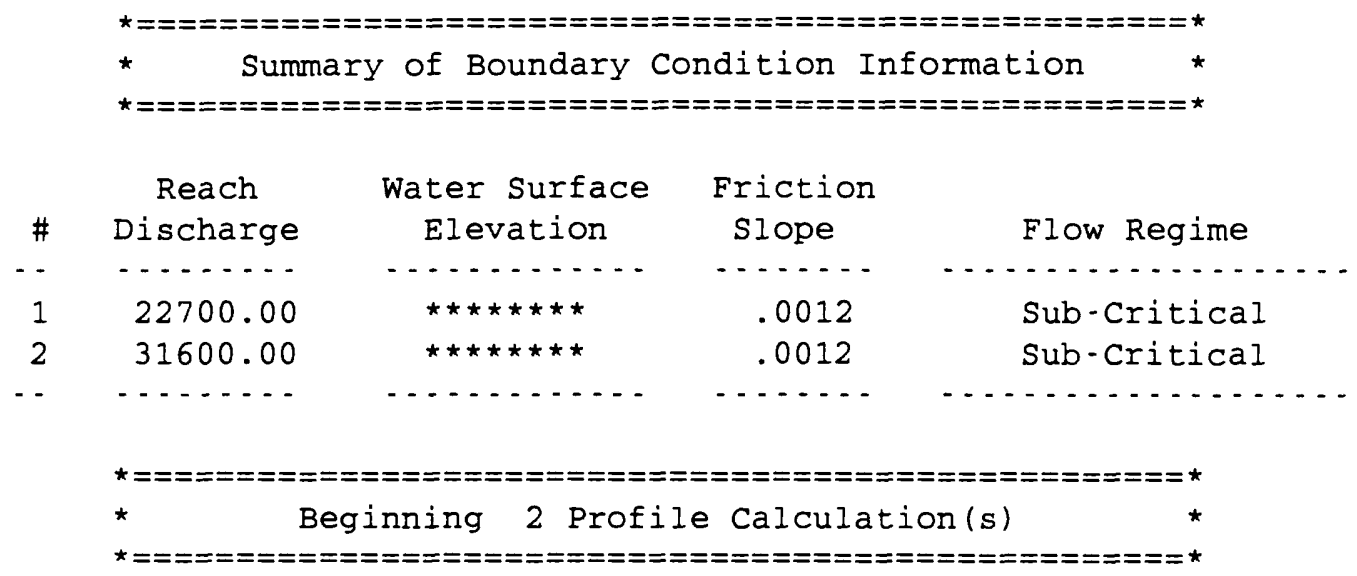

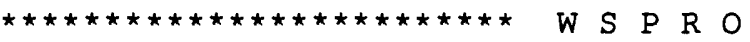

Federal Highway Administration - U. S. Geological Survey Model for water-Surface Profile Computations. Input Units: English / Output Units: English I 74 OVER EAGLE CREEK COUNTY : MARION

$11-14-96$

$I 74-70-4437$

QUAD: CLERMONT 110D

BRET A. ROBINSON
}

\begin{tabular}{|c|c|c|c|c|c|c|}
\hline & WSEL & VHD & $Q$ & AREA & SRDL & LEW \\
\hline & EGEL & $\mathrm{HF}$ & $\mathrm{V}$ & $\mathrm{K}$ & FLEN & REW \\
\hline & CRWS & $\mathrm{HO}$ & FR \# & SF & ALPHA & ERR \\
\hline & $\ldots \ldots$ & $\ldots \ldots$ & $\ldots \ldots \ldots$ & $\ldots \ldots$ & $\ldots \ldots$ & $\ldots \ldots$ \\
\hline Section: EXIT & 755.125 & .612 & 22700.000 & 5471.388 & 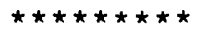 & 74136.680 \\
\hline Header Type: XS & 755.737 & 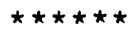 & 4.149 & 654930.10 & 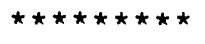 & 75595.160 \\
\hline .000 & 750.541 & $\star \star \star \star \star \star$ & .571 & 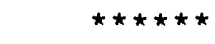 & 2.286 & $\star \star \star \star \star \star$ \\
\hline
\end{tabular}




\section{WSPRO OUTPUT}

\begin{tabular}{|c|c|c|c|c|c|c|}
\hline Header Type: FV & 756.017 & .278 & 3.788 & 708470.10 & 250.000 & 75627.840 \\
\hline 250.000 & 750.541 & .000 & .524 & .0011 & 2.429 & .003 \\
\hline \multicolumn{7}{|c|}{$\ll$ The Preceding Data } \\
\hline Section: APPR & 756.190 & .163 & 22700.000 & 7017.645 & 375.0007 & 74186.340 \\
\hline \multirow{2}{*}{ 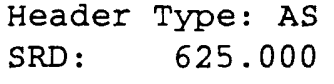 } & 756.353 & .336 & 3.235 & 812811.60 & 375.0007 & 75811.630 \\
\hline & 751.706 & .000 & .274 & .0009 & 1.000 & .000 \\
\hline \multicolumn{7}{|c|}{$\ll$ The Preceding Data } \\
\hline \multicolumn{7}{|c|}{$\begin{array}{c}\ll<\text { The Following Data Reflect The "Constricted" Profile }>>> \\
<<\text { Beginning Bridge/Culvert Hydraulic Computations }>>>\end{array}$} \\
\hline & WSEL & VHD & $Q$ & AREA & SRDL & LEW \\
\hline & EGEL & $\mathrm{HF}$ & $\mathrm{V}$ & $\mathrm{K}$ & FLEN & REW \\
\hline & CRWS & HO & FR \# & SF & ALPHA & ERR \\
\hline & ......... & $\ldots \ldots$ & $\ldots \ldots \ldots$ & $\ldots \ldots \ldots$ & $\ldots \ldots \ldots$. & $\ldots \ldots \ldots$ \\
\hline Section: BRDGE & 754.747 & 2.520 & 22700.000 & 2070.282 & 250.0007 & 74904.000 \\
\hline Header Type: BR & 757.266 & .481 & 10.965 & 420485.50 & 250.0007 & 75106.270 \\
\hline 250.000 & 751.682 & 1.046 & .701 & 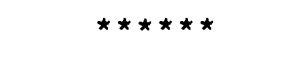 & 1.348 & -.006 \\
\hline \multirow{3}{*}{$\begin{array}{l}\text { Specific Bridge } \\
\text { Bridge Type } 3 \\
\text { Pier/Pile Code }\end{array}$} & Information & C & $\mathrm{P} / \mathrm{A}$ & BLEN & $X \perp A B$ & $\mathrm{XRAB}$ \\
\hline & Flow Type 1 & $\ldots .$. & $\ldots \ldots$ & $\ldots \ldots$ & - $\ldots \ldots$ & $-\ldots \ldots$ \\
\hline & 0 & .8615 & .028 & 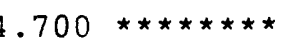 & 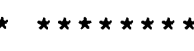 & 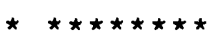 \\
\hline \multicolumn{2}{|c|}{ 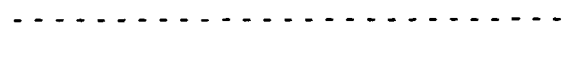 } & $\ldots .$. & $\ldots \ldots$ & $\ldots \ldots$ & $\ldots \ldots$ & $-\ldots \ldots$. \\
\hline & WSEL & VHD & Q & AREA & SRDL & LEW \\
\hline & EGEL & HF & $\mathrm{v}$ & $\mathrm{K}$ & FLEN & REW \\
\hline & CRWS & HO & FR \# & SF & ALPHA & ERR \\
\hline & & & & & & \\
\hline I : APPR & 757.887 & .079 & 22700.000 & 10063.630 & 250.0007 & 73978.590 \\
\hline Header Type: AS & 757.966 & .280 & 2.256 & 1306773.00 & $288.677 \quad 7$ & 75942.330 \\
\hline 625.000 & 751.706 & .424 & .176 & .0009 & 1.000 & .017 \\
\hline
\end{tabular}

Approach Section APPR Flow Contraction Information

\begin{tabular}{|c|c|c|c|c|c|}
\hline G I & $M(K)$ & $\mathrm{KQ}$ & XLKQ & XRKQ & OTEL \\
\hline 373 & 01 & 778737.9 & 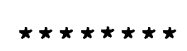 & 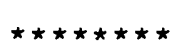 & 757.887 \\
\hline
\end{tabular}

$<<$ End of Bridge Hydraulics Computations >>>

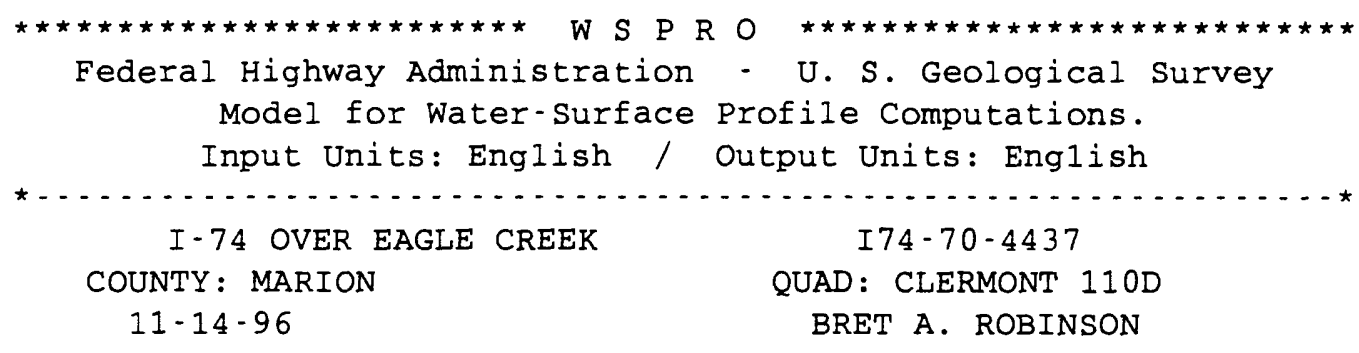


WSPRO OUTPUT

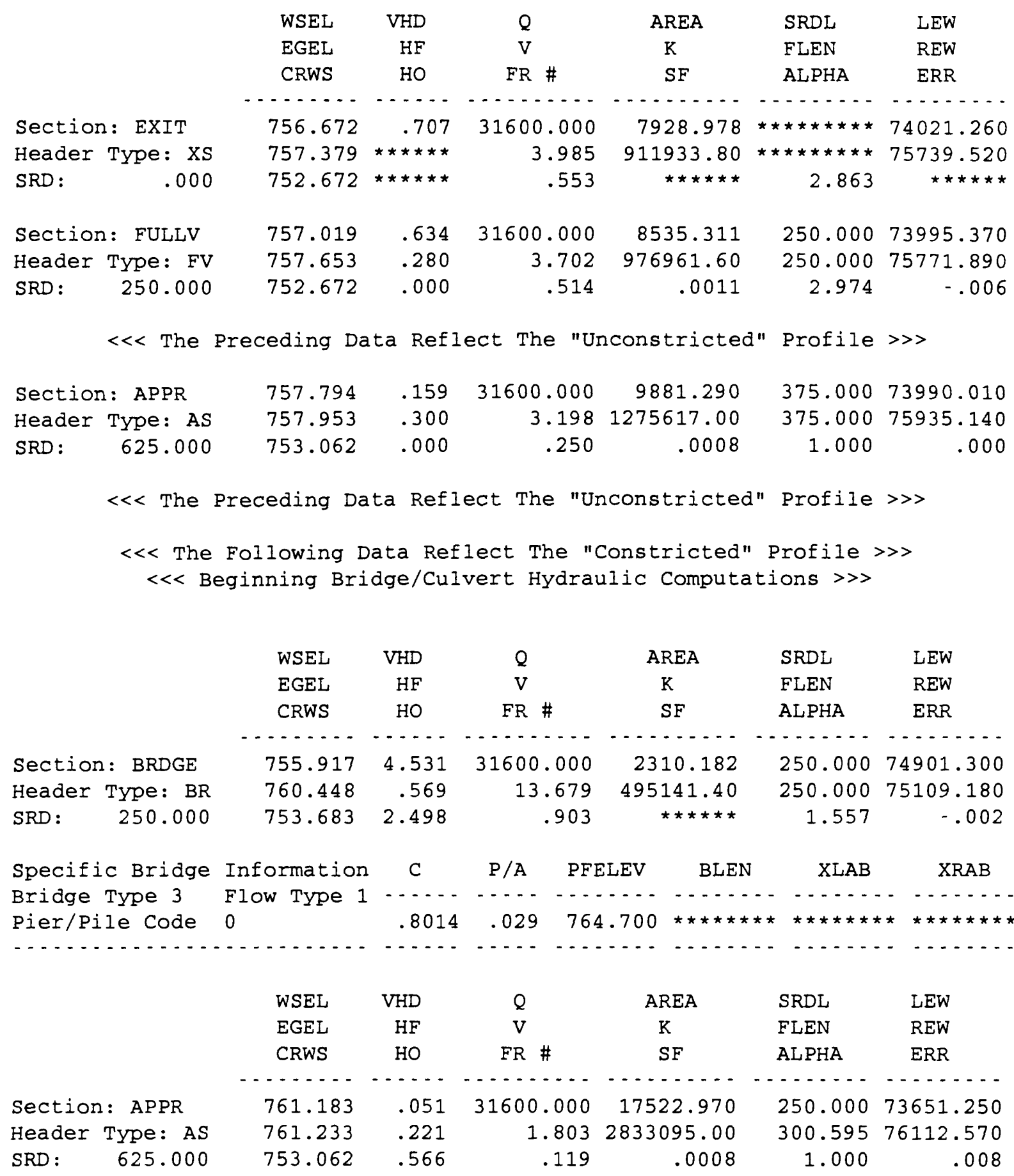

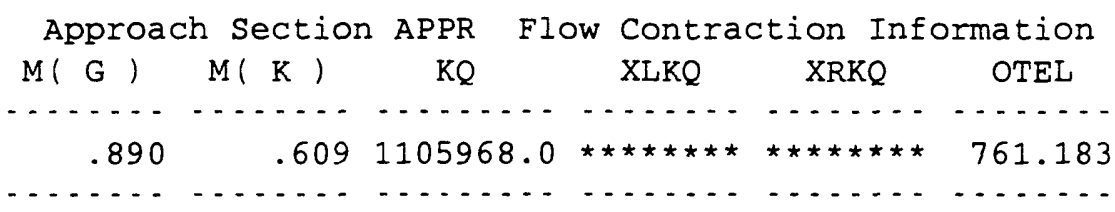

$\ll$ End of Bridge Hydraulics Computations $\gg>$ 


\title{
WSPRO OUTPUT
}

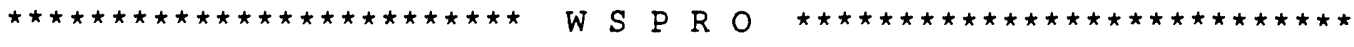 \\ Federal Highway Administration - U. S. Geological Survey \\ Model for Water-Surface Profile Computations. \\ Input Units: English / Output Units: English \\ *** Live-Bed Contraction Scour Calculations for Header Record BRDGE \\ Constants and Input Variables

\begin{tabular}{|c|c|c|}
\hline $\begin{array}{l}\text { Bed Material Transport Mode Factor } \\
\text { Total Pier Width Value }\end{array}$ & $\begin{array}{l}(\mathrm{k} 1): \\
(\mathrm{Pw}):\end{array}$ & 8.000 \\
\hline
\end{tabular}

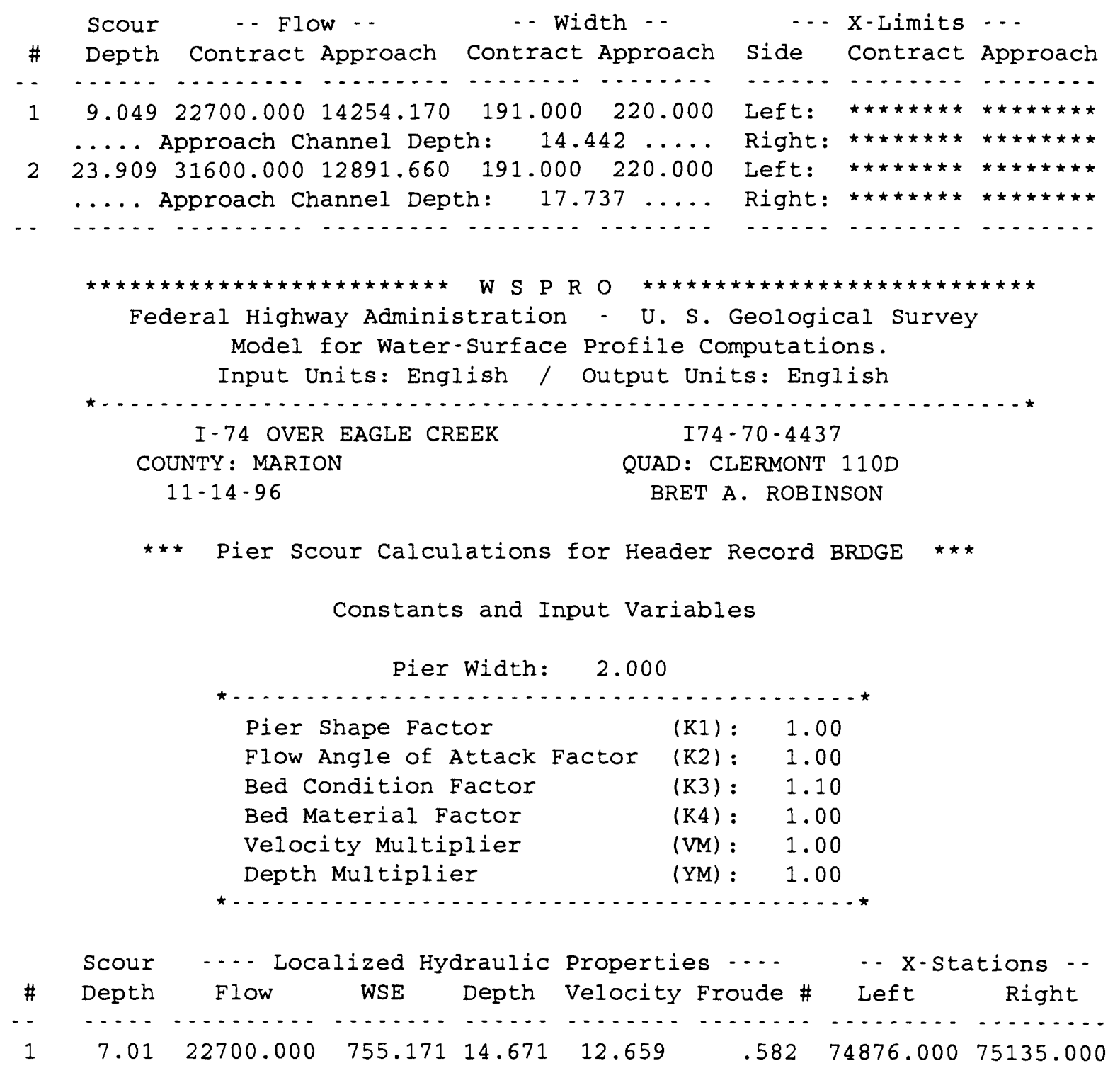




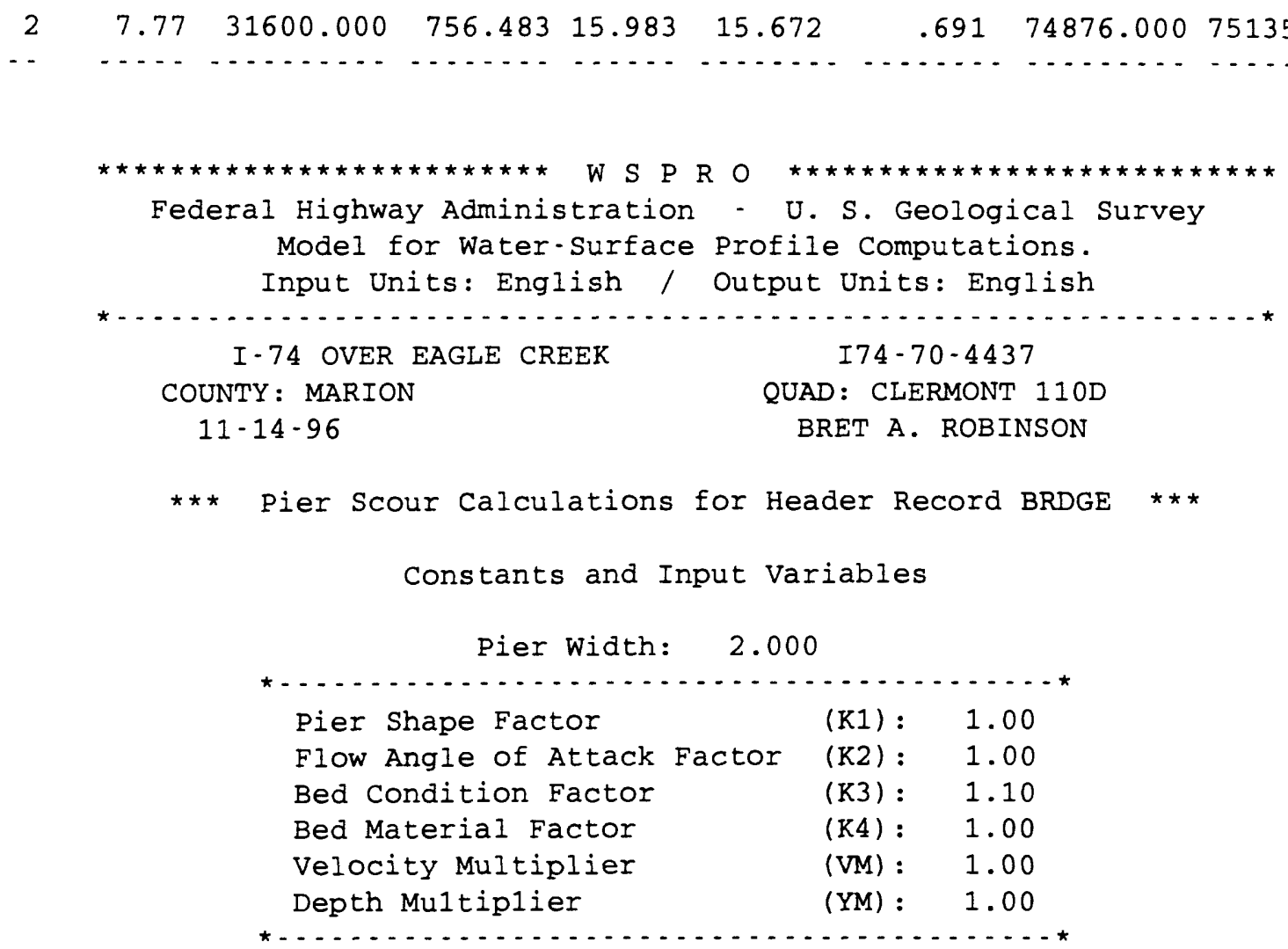

\begin{tabular}{|c|c|c|c|c|c|c|c|c|}
\hline \multirow[b]{2}{*}{ \# } & \multirow{2}{*}{$\begin{array}{l}\text { Scour } \\
\text { Depth }\end{array}$} & \multicolumn{2}{|c|}{... Localized } & \multirow{2}{*}{$\begin{array}{c}\text { Hydraulic } \\
\text { Depth }\end{array}$} & \multicolumn{2}{|c|}{ Properties } & \multicolumn{2}{|c|}{ - x-stations -. } \\
\hline & & Flow & WSE & & Velocity & Froude \# & Left & Right \\
\hline - - & $\ldots \ldots$ & $\ldots \ldots$ & $\ldots .$. & $\ldots \ldots$ & $\ldots \ldots .$. & $\ldots . .$. & $\ldots \ldots$ & \\
\hline 1 & 7.01 & 22700.000 & 755.171 & 14.671 & 12.659 & .582 & 74876.000 & 75135.000 \\
\hline 2 & 7.77 & 31600.000 & 756.483 & 15.983 & 15.672 & .691 & 74876.000 & 75135.000 \\
\hline & $\ldots$ & $\ldots \ldots$ & $\ldots \ldots$ & $\ldots .$. & $\ldots \ldots$ & $\ldots .$. & $\ldots . . .$. & $\ldots$ \\
\hline
\end{tabular}

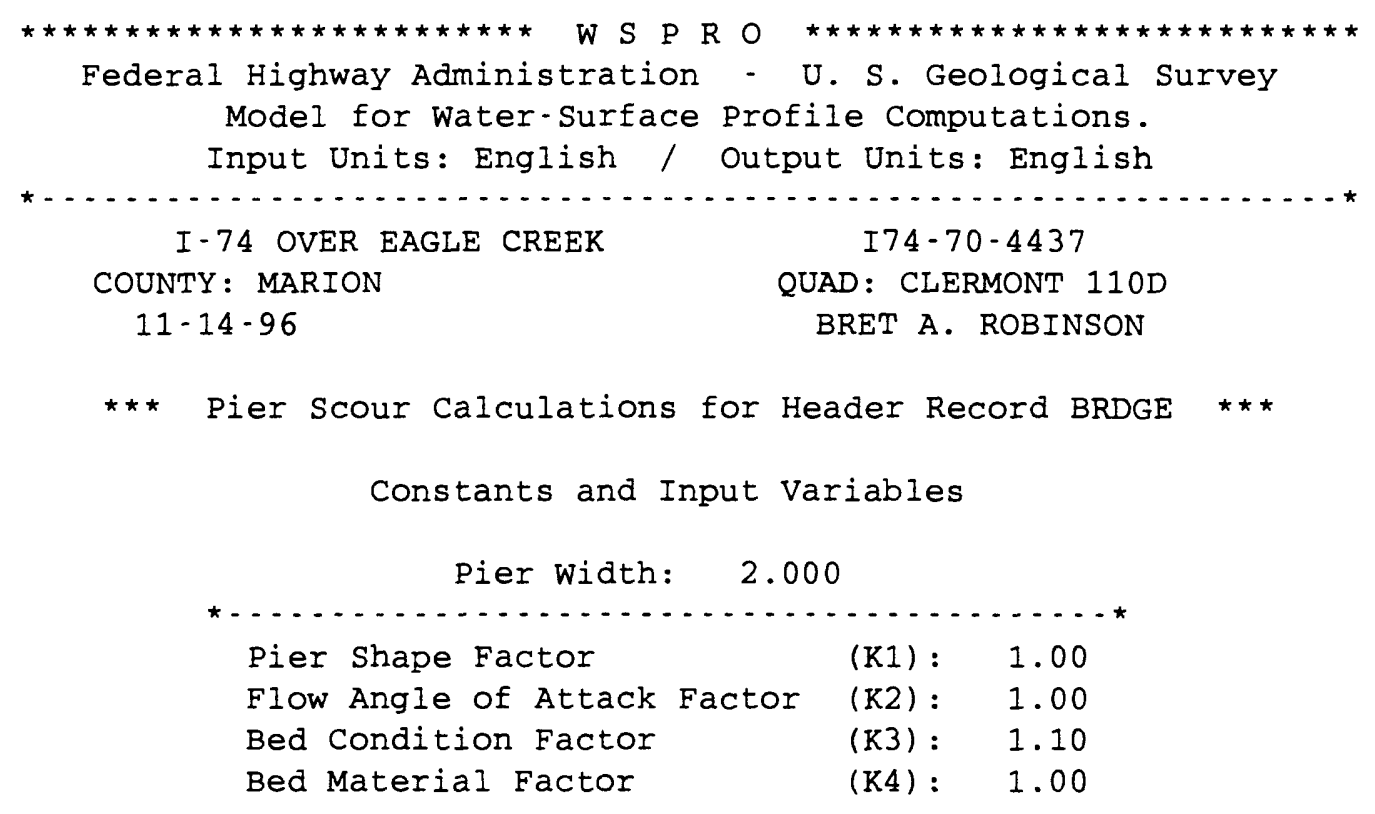




\section{WSPRO OUTPUT}

\begin{tabular}{|c|c|c|c|c|c|c|c|c|}
\hline \multirow[b]{4}{*}{ \# } & \multicolumn{4}{|c|}{$\begin{array}{l}\text { Velocity Multiplier } \\
\text { Depth Multiplier }\end{array}$} & \multicolumn{4}{|c|}{1.00} \\
\hline & \multicolumn{8}{|c|}{ 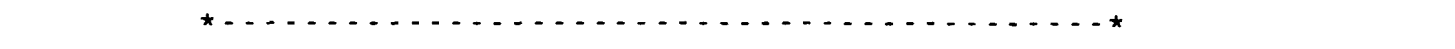 } \\
\hline & Scour & $\ldots$ LOĆ & lized $\mathrm{Hy}$ & draulic & Propertie & 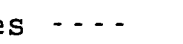 & $\cdots x-s t a$ & ations - - \\
\hline & Depth & Flow & WSE & Depth & Velocity & Froude \# & Left & Right \\
\hline-- & $\ldots .-$ & $\ldots \ldots . . . .$. & $\ldots \ldots$ & $\ldots \ldots$ & $\ldots \ldots$ & $\ldots \ldots$ & $\ldots \ldots$ & $\ldots \ldots$ \\
\hline 1 & 7.01 & 22700.000 & 755.171 & 14.671 & 12.659 & .582 & 74876.000 & 75135.000 \\
\hline 2 & 7.77 & 31600.000 & 756.483 & 15.983 & 15.672 & .691 & 74876.000 & 75135.000 \\
\hline - & $\ldots$. & $\ldots \ldots$ & $\ldots$ & $\ldots \ldots$ & $\ldots \ldots$ & $\ldots \ldots$ & $\ldots \ldots$ & $\ldots \ldots$ \\
\hline
\end{tabular}

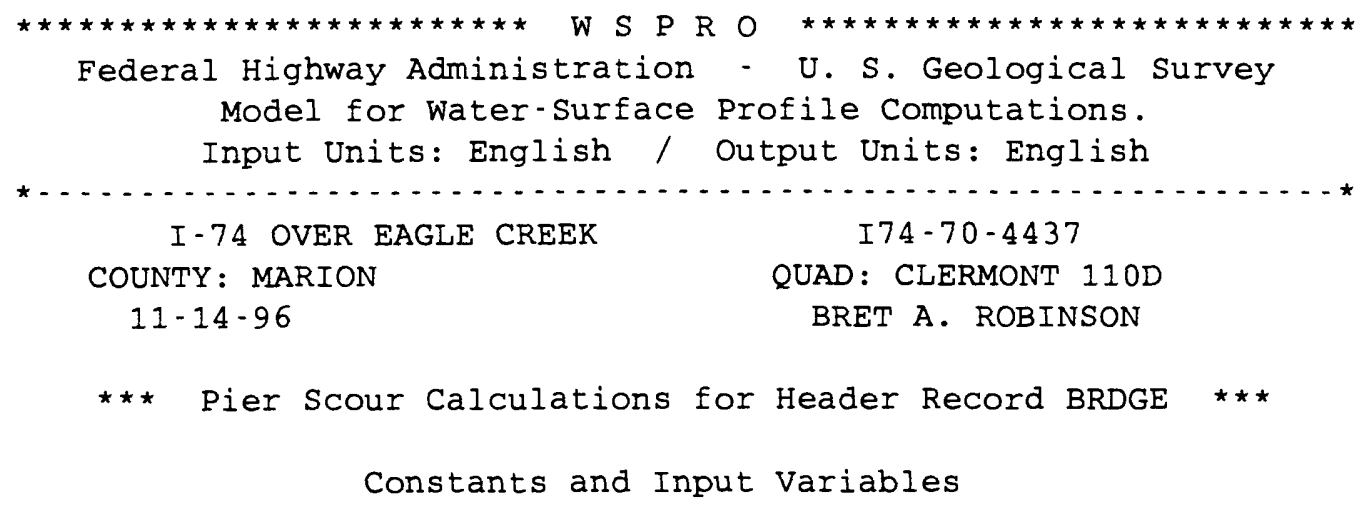

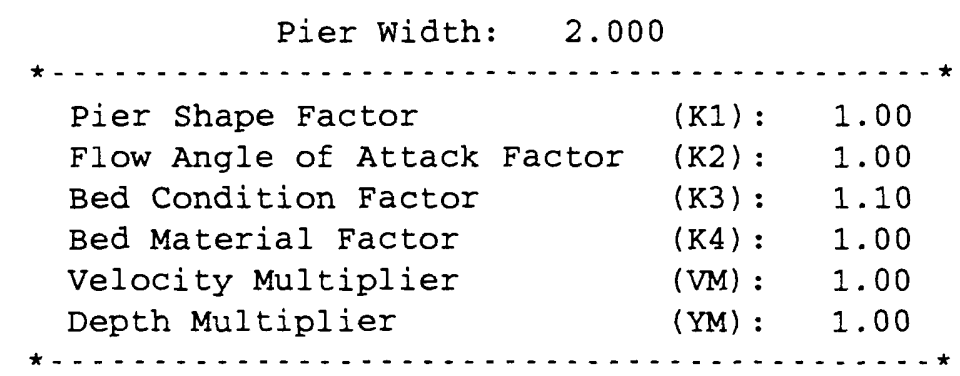

\begin{tabular}{|c|c|c|c|c|c|c|c|c|}
\hline \multirow[b]{2}{*}{$\#$} & \multirow{2}{*}{$\begin{array}{l}\text { Scour } \\
\text { Depth }\end{array}$} & \multicolumn{2}{|c|}{.... Localized } & \multirow{2}{*}{$\begin{array}{c}\text { Hydraulic } \\
\text { Depth }\end{array}$} & \multicolumn{2}{|c|}{ Properties } & \multicolumn{2}{|c|}{ - x-stations -. } \\
\hline & & Flow & WSE & & Velocity & Froude \# & Left & Right \\
\hline- & $\ldots \ldots$ & $\ldots \ldots$ & $\ldots \ldots$ & $\ldots \ldots$ & $\ldots \ldots$ & $\ldots \ldots$ & $\ldots \ldots$ & $\ldots \ldots$ \\
\hline 1 & 7.01 & 22700.000 & 755.171 & 14.671 & 12.659 & .582 & 74876.000 & 75135.000 \\
\hline 2 & 7.77 & 31600.000 & 756.483 & 15.983 & 15.672 & .691 & 74876.000 & 75135.000 \\
\hline & $\ldots$ & $\ldots \ldots$ & $\ldots \ldots$ & $\ldots \ldots$ & $\ldots \ldots$ & $\ldots \ldots$ & $\ldots \ldots$ & $\ldots \ldots$ \\
\hline
\end{tabular}

ER 